\title{
Schistosoma mansoni infection and undernutrition among school age children in Fincha'a sugar estate, rural part of West Ethiopia
}

\author{
Zeleke Mekonnen ${ }^{1 *}$, Selima Meka ${ }^{1}$, Ahmed Zeynudin ${ }^{1}$ and Sultan Suleman ${ }^{2}$
}

\begin{abstract}
Background: Parasitic infection like schistosomiasis is known to exert a negative effect on nutritional status of school-aged children. However, studies associating parasitic infections with undernutrition are scarce. Thus, this study was primarily to document the association between Schistosoma mansoni infection and undernutrition among school-aged children in a rural setting of Fincha'a Sugar Estate, Ethiopia.

Methods: A cross-sectional study was conducted on a total of 453 school-aged children (5-18 years). Stool specimen was collected and examined using the standard Kato-katz technique. Children's height-for-Age Z-score (HAZ) and Body mass index-for-Age Z- score (BAZ) was determined. Z-Scores for each nutritional index were compared with the WHO child growth standards reference values. Children were considered stunted or wasted as HAZ or BAZ falls below -2 standard deviations, respectively.

Result: The overall prevalence of Schistosoma mansoni infection was 53.2\%. Out of the total school children examined, $11.5 \%$ and $13.2 \%$ were stunted and wasted, respectively. Multivariate logistic regression analysis was done to determine the relationship between Schistosoma mansoni infection and nutritional status controlling for other factors. Accordingly, stunting was not significantly associated while wasting was negatively associated with Schistosoma mansoni infection. Paternal occupation was the best predictor of stunting and wasting such that, unemployed fathers have $4.28(95 \% \mathrm{Cl} ; 2.13,8.63)(\mathrm{p}<0.001)$ and $3.83,95 \% \mathrm{Cl} ; 1.89,7.79)(\mathrm{p}<0.001)$ chance of having stunted and wasted children, respectively.

Conclusion: Schistosoma mansoni infection is highly prevalent in the study area. The high prevalence of wasting, and moderate level of stunting among study subjects in this study area indicate that they are affected by both infection and undernutrition. Therefore, regular preventive chemotherapy against $S$. mansoni and other control measures are recommended. Moreover, possibilities of synchronized nutritional rehabilitation and creation of employment opportunities to the families should be looked for.
\end{abstract}

Keywords: Schistosoma mansoni, Under nutrition, Stunting, Wasting, School children, Ethiopia

\section{Background}

In the past, nutrition and health of school-aged children and adolescents in the developing world received little attention relative to those less than five years of age. However, there is increasing evidence, resulting in international concern, that the high level of nutritional deprivation combined with the heavy burden of disease in school age

\footnotetext{
* Correspondence: zeleke.mekonnen@ju.edu.et

'Department of Medical Laboratory Sciences and Pathology, College of Public Health and Medical Sciences, Jimma University, P.O. Box 378, Jimma, Ethiopia

Full list of author information is available at the end of the article
}

group has negative consequences for a child's long term overall development. This has prompted an increased focus on the diverse needs of the school-aged child [1-3].

Recent studies on school-aged children have shed new information on stunting, wasting and underweight for this age group [4-6]. Currently, about one-fourth of African primary school children lie under the fifth centile of United States- National Center for Health Statistics (US-NCHS) reference for Height-for-Age Z-score (HAZ). While undernutrition prevalence has decreased significantly in most 
other developing countries in the last few years, it has been nearly static for sub-Sahara Africa [7].

While factors affecting growth and development of preschool children are well-documented, the factors influencing growth of school-aged children are not as such clearly elucidated $[8,9]$. One of the factors emphasized in the 1993 World Bank report was the relationship between parasitic infection and undernutrition [10]. Moreover, the relationship between undernutrition and soil transmitted helminth infection has been well established [11-13], but such studies have been limited only to soil transmitted helminth infections in children [14-17].

However, the relationship between undernutrition and schistosomiasis is now gaining more attention. There are few studies which associate the different species of schistosoma with linear growth retardation in children $[5,18,19]$. This parasitic infection is known to exert a negative effect on the nutritional status of school-aged children even at a low to moderate intensity of infection $[20,21]$. Such studies are limited in developing countries like Ethiopia, where schistosomiasis is endemic. The aim of this study was, therefore, to investigate the association between S. mansoni infections and prevalence levels of undernutrition, and related associated risk factors influencing this relationship among school-aged children in a rural setting of Fincha'a Sugar Estate, Western Ethiopia.

\section{Methods}

\section{Study area and population}

A cross-sectional study was conducted from February March, 2011 among school-aged children (5-18 years) residing in a rural village of Fincha'a Sugar Estate in Horo Guduru Wollega, western Ethiopia. Fincha'a Sugar Estate is found in Oromia regional government and located at $350 \mathrm{~km}$ west of Addis Ababa (Capital of Ethiopia). Fincha'a valley is bounded by escarpments from east, west and south situated at a latitude of $9^{\circ}$ $30^{\prime} \mathrm{N}$ to $10^{\circ} 60^{\prime} \mathrm{N}$ and a longitude of $37^{\circ} 15^{\prime}$ to $37^{\circ} 30^{\prime} \mathrm{E}$. The area is characterized by a semi-arid type climate having the mean maximum and mean minimum temperatures of $30.6^{\circ} \mathrm{C}$ and $14.5^{\circ} \mathrm{C}$, respectively. It is situated $1,350 \mathrm{~m}-1,600 \mathrm{~m}$ above sea level with mean relative humidity of $62 \%$ and receiving mean annual precipitation of $1,485 \mathrm{~mm}$. The population comprises of different ethnic groups that settled at different times in search of job opportunities. The total population of the area is estimated to be over 18,000 according to the 2007 population census, with male/female ratio of approximately 1.1:1.0 [22]. All kind of basic health services were provided by one health center and 5 small clinics to all communities residing in the sugar farm (camp) across the different villages.

The Fincha'a Sugar Estate was selected purposively as the area is a focus of $S$. mansoni infections due to its favorable environment (sugarcane cultivation and availability of a special watershed of the hydropower dam reservoir). The sugar factory was organized into 5 farm villages (Village A, B, C, D, and E) and two small towns (Agamsa and Kuyisa). From a total of 5 villages in the area, two (village ' $A$ ' and ' $E$ ') were selected using lottery method for this study (Figure 1). The sample size was determined assuming a confidence interval of $95 \%$ and a $60 \%$ prevalence of S. mansoni in the study area. A sample size of 458 was considered to be adequate, of which 453 students (242 from village 'A' and 211 from village 'E') participated after the sample size was proportionally distributed over the two villages based on the total households in each of the two villages. Then, one child from each randomly selected household was recruited using simple random sampling technique for inclusion in the study. The variables used for inclusions were age range of 5-18 years, lived primarily in the study village at least for the last two years, provided both child assent and parental consent and being asymptomatic for other diseases at the time of data collection.

\section{Socio-economic data}

Data on socio-demographic data such as age, sex, parental and maternal educational status and occupational status was obtained by interviewing parents and legal guardians guided by pre-tested structured questionnaire. Data on socio-economic status addressing household durable assets (radio, television, bicycle, mobile phone etc), three components of dwelling structure (roof, floor and wall type) and number of rooms for dwelling were assessed. Questions dealing with household asset index were adopted from Ethiopia demographic and health survey 2005 [23]. A household wealth index was constructed from 20 variables using principal component analysis. Commonly used arbitrary cut-off points were applied to classify children as the lowest $40 \%$ of the socio-economic status score into 'poor', the highest $20 \%$ as 'rich' and the rest as the 'middle' group [24].

\section{Stool examination}

Standard Kato-katz cellophane faecal thick smear method (41.7 mg template) was utilized to examine three consecutive days stool specimen for the presence of Schistosoma mansoni, Ascaris lumbricoides, Trichuris trichiura and hookworm infection. Microscopic examination was done within 30-60 min of smear preparation not to miss hookworm infection since the sensitivity of Kato-katz techniques to detect hookworm decreases after an hour [25]. The mean intensity of infection was expressed as eggs per gram (epg) and classified according to World Health Organization (WHO) criteria as low (1-99 epg), moderate (100-399 epg), and heavy ( $\geq 400 \mathrm{epg}$ ) intensity infection [26]. 


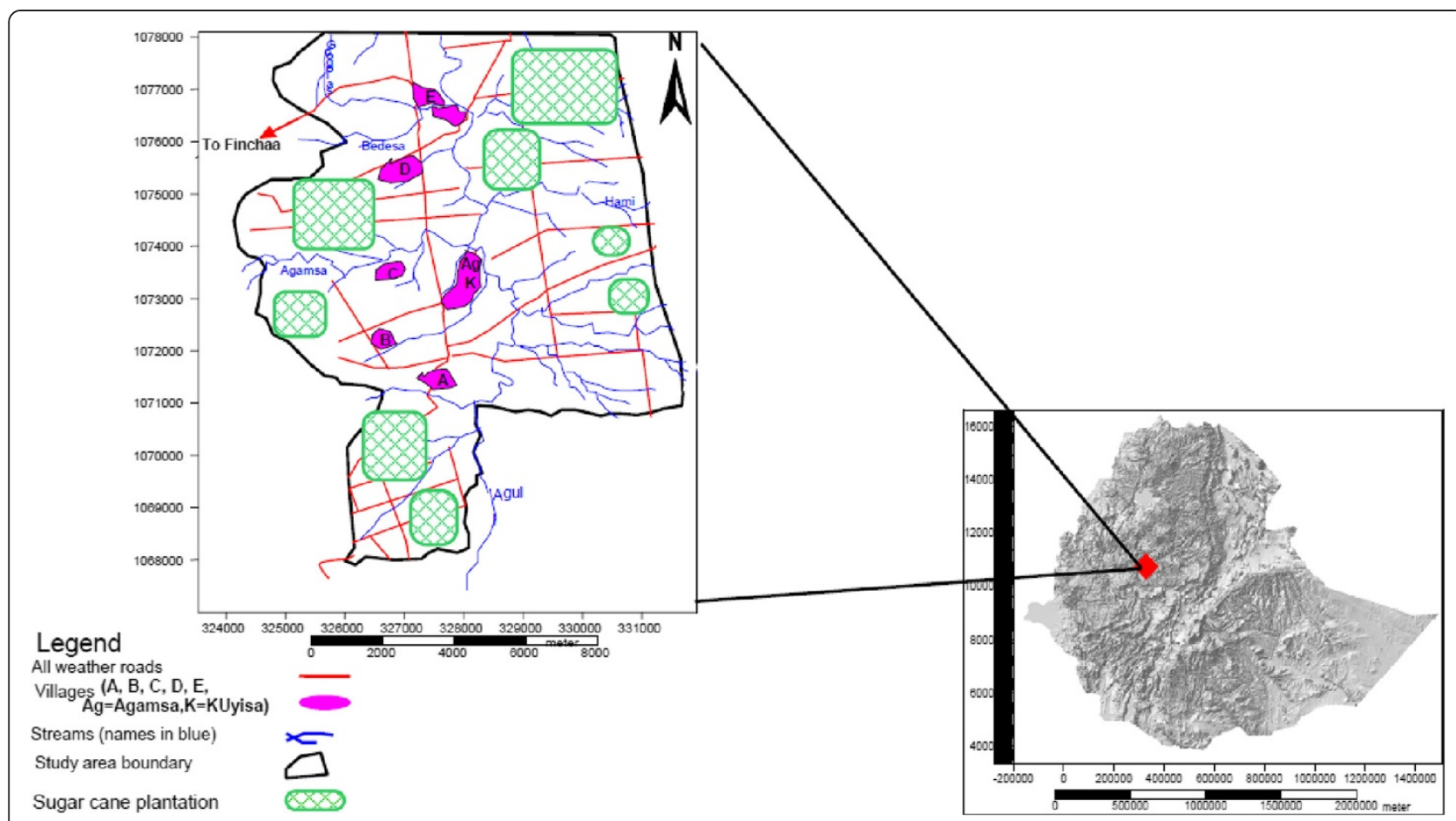

Figure 1 Map of study villages within Fincha'a sugar factory, West Ethiopia. [Source: MSc document (Bayissa Chala), AAU, 2007].

\section{Anthropometric measures}

Body weight with light clothing was measured to the nearest $0.1 \mathrm{~kg}$ on a Seca Model 880 Digital scale (Hanover, $\mathrm{MD}$, Germany). Height was measured barefooted to the nearest $0.1 \mathrm{~cm}$ using a portable stadiometer that was taped to a wall at the same location for each measurement. Height-for-Age Z-score (HAZ) and Body mass index forAge Z-score (BAZ) were based on the WHO child growth standards. Body mass index (BMI) is the index of choice for the assessment of recent under-nutrition in both adults and adolescents [27]. Stunting was defined as $\mathrm{HAZ}<-2$ standard deviations (SDs) and wasting or wasted if BAZ $<-2$ SDs compared with a normal, healthy reference population. As part of data quality assurance, in addition to test-retest and inter-rater reliability assessments, all anthropometric measurements were taken with calibrated and validated instruments.

Age of each participant was collected from the mother and counter checked using vaccination cards, baptismal certificates or other forms of informal recording. When these recordings were not available, a calendar of locally important events was used. The $15^{\text {th }}$ day of the month was used when the date of birth is unknown and if the month of birth is unknown, the midpoint of the year of birth was used.

\section{Data processing}

Data were coded and entered into SPSS for windows version 17 statistical software package for analysis of variables after being checked for completeness and cleaned of any inconsistencies. Simple frequency and percentages were used as the statistical parameter in the descriptive analysis. Bivariate logistic regression was used to identify predictors for under-nutrition. Multivariate logistic regression analysis was used to provide independent estimates of the relationships of interest. $\mathrm{P}<0.05$ was considered significant.

\section{Ethical consideration}

Ethical clearance was obtained from Ethical Clearance Committee of Jimma University. The study participants involved in the study after informed written consent was obtained from their parents or guardians and assent from participating children. Children positive for S. mansoni have received single dose of praziquantel (Biltricide ${ }^{\bullet}$, Bayer AG, Germany), $40 \mathrm{mg} / \mathrm{kg}$ body weight according to standard treatment guideline of Ethiopia (2010) and study participants identified as stunted and wasted were referred to Fincha'a sugar estate health center for necessary interventions.

\section{Results}

A total of 458 children between 5-18 years of age were recruited in the study. Complete parasitological results were available for 453 (98.9\%), as 5 were withdrawn since they were unfit to the inclusion criteria. Out of the total study participants $216(47.7 \%)$ were males and 237 (52.3\%) were females. Most of the study participants (62.7\%) belongs to the age group 10-14 followed by 
$25.6 \%$ in the age group 5-9 (Table 1). The mean HAZ and BAZ were $-0.69 \pm 1.13 \mathrm{SD}$ and $-0.83 \pm 0.96 \mathrm{SD}$, respectively. The overall prevalence of stunting was $11.5 \%$ and $13.2 \%$ were wasted. The overall prevalence of $S$. mansoni infection was $53.2 \%$ with a mean \pm SD intensity of $358 \pm 477 \mathrm{epg}$. The infection intensity was light in $21.4 \%$, moderate in $15.7 \%$ and heavy in $16.1 \%$ of the participants. Soil transmitted helminthes were not detected in any of the study participants.

\section{Stunting and Schistosoma mansoni infection}

Bivariate logistic regression analysis showed that, stunting was not associated with S. mansoni infection. However, it was related with mother's literacy and father's occupational status. Accordingly, children born from illiterate mothers were about 3 times (95\% CI; 1.19, 6.89) more likely to be stunted ( $\mathrm{p}=0.02$ ) than their counterparts. Children of unemployed fathers had about 5 times $(95 \%$ CI; 2.49, 9.86) higher risk of being stunted ( $p<0.001$ ) than children of employed fathers (Table 2).

Multivariate logistic regression analysis was conducted to fit into a model including all variables with a $P$-value $<0.25$ in the bivariate analysis for stunting. Therefore, gender, age group of the study participants, mother's educational status and paternal occupation were included in the model for analysis. Controlling for other factors, paternal employment was the best predictor of stunting among school-age children such that, unemployed fathers have about 4 times (95\% CI; 2.13, 8.63) more chance of having stunted children $(\mathrm{p}<0.001)$ (Table 2$)$.

\begin{tabular}{|c|c|c|c|}
\hline \multicolumn{2}{|c|}{ Socio-demographic variables } & \multirow{2}{*}{$\begin{array}{c}\text { Frequency } \\
\text { n (\%) } \\
216(47.7)\end{array}$} & \multirow{2}{*}{$\begin{array}{c}\begin{array}{c}\text { Total } \\
\text { n (\%) }\end{array} \\
453(100)\end{array}$} \\
\hline Gender & Male & & \\
\hline & Female & $237(52.3)$ & \\
\hline \multirow[t]{3}{*}{ Age group } & $5-9$ & $116(25.6)$ & $453(100)$ \\
\hline & $10-14$ & $284(62.7)$ & \\
\hline & $15-18$ & $53(11.7)$ & \\
\hline \multirow[t]{2}{*}{ Maternal literacy } & Illiterate & $338(74.6)$ & $453(100)$ \\
\hline & Literate & $115(25.4)$ & \\
\hline \multirow[t]{2}{*}{ Paternal literacy } & Illiterate & $321(70.8)$ & $453(100)$ \\
\hline & Literate & $132(29.2)$ & \\
\hline \multirow[t]{2}{*}{ Maternal occupation } & Unemployed & $395(87.2)$ & $453(100)$ \\
\hline & Employed & $58(12.8)$ & \\
\hline \multirow[t]{3}{*}{ Paternal occupation } & Unemployed & $48(10.6)$ & $453(100)$ \\
\hline & Employed & $405(89.4)$ & \\
\hline & Total & & $453(100)$ \\
\hline
\end{tabular}

\section{Wasting and Schistosoma mansoni infection}

Wasting was significantly associated with S. mansoni infection. Overall, S. mansoni infected children were 0.45 times $(95 \% \mathrm{CI} ; 0.25,0.81)$ less likely to be wasted (Table 3), where as children with light infection (21.4\%) were about 2 times less likely to be wasted than uninfected children $(\mathrm{p}=0.01)$. Wasting was also associated with gender, maternal literacy and paternal occupation. Males were 2.69 times $(95 \% \mathrm{CI} ; 1.51,4.79)$ more likely to be wasted than their female counters $(\mathrm{p}=0.001)$. Children born from illiterate mothers were about 4 times $(95 \% \mathrm{CI}$; $1.67,10.96)$ more likely to be wasted than children born from literate mothers $(\mathrm{p}=0.002)$. Likewise, children born from unemployed fathers were about 4 times (95\% CI; $2.29,8.69)$ more likely to be wasted than their counter parts ( $p<0.0001)$. Controlling for other factors, the AOR indicates that father's employment status is the best predictor of wasting among school age children (AOR $=3.83$, 95\% CI; 1.89, 7.79) $(\mathrm{p}<0.001)$.

\section{Discussion}

Undernutrition continues to be a major health burden in developing countries. Since parasitic infections cause anorexia and poor absorption of nutrients and promote the deviation of nutrients to the organism's defense mechanisms, they contribute to the onset or exacerbation of weight and height deficits [28,29]. Previous cross-sectional studies have reported clear relationship between $S$. mansoni infection and nutritional status.

The mean HAZ and BAZ were below zero indicating that the distribution was shifted downwards [30]. The overall prevalence of stunted and wasted school-aged children in Fincha'a Sugar Estate was $11.5 \%$ which is considered low $(<20 \%)$ according to the WHO classification [30]. Similarly, the prevalence of wasting was $13.2 \%$, which is considered high (10-14\%).

When these figures were compared with other study, stunting was almost $1 / 3$ of the prevalence reported among school-aged children of Peru [31]. This could be attributed to the difference in transmission of geohelminth in the two study areas. In our study, STH infection was not detected from any of the participants. However, $86 \%$ of the children from Peru were infected with at least one helminth and these may also have had an impact on nutritional status and contributed to high prevalence of stunting. Previously, it has been established that soil transmitted helminth infections are associated with stunting in pre-school and school children $[32,33]$. The prevalence of wasting on the other hand was comparable with this study. This could be due to wasting being an indicator of acute nutritional insult might not be affected by intestinal parasites. This has been confirmed by significant negative relation between 
Table 2 Bivariate and multivariate logistic regression analysis of factors associated with stunting amongst school age children residing in Fincha'a Sugar Estate, Horo Guduru Wollega, Ethiopia, Feb-Mar, 2011

\begin{tabular}{|c|c|c|c|c|c|c|}
\hline Variables & $\begin{array}{c}\text { Stunted } \\
\text { n (\%) }\end{array}$ & $\begin{array}{c}\text { Normal } \\
\text { n (\%) }\end{array}$ & $\begin{array}{c}\text { COR } \\
(95 \% \mathrm{Cl})\end{array}$ & P-value & $\begin{array}{c}\text { AOR } \\
(95 \% \mathrm{Cl})\end{array}$ & P-value \\
\hline \multicolumn{7}{|l|}{ Gender } \\
\hline Female & $23(9.7)$ & $214(90.3)$ & 1.00 & & 1.00 & \\
\hline Male & $29(13.4)$ & $187(86.6)$ & $1.44(0.81,2.58)$ & 0.22 & $1.25(0.69,2.29)$ & 0.46 \\
\hline \multicolumn{7}{|l|}{ Age group } \\
\hline $5-9$ & $12(10.3)$ & $104(89.7)$ & 1 & & - & \\
\hline $10-14$ & $30(10.6)$ & $254(89.4)$ & $1.02(0.51,2.08)$ & 0.95 & - & \\
\hline $15-18$ & $10(18.9)$ & $43(81.1)$ & $2.02(0.81,5.01)$ & 0.13 & - & \\
\hline \multicolumn{7}{|l|}{ S. mansoni } \\
\hline Uninfected & $26(12.3)$ & $186(87.7)$ & 1.00 & & - & \\
\hline Infected & $26(10.8)$ & $215(89.2)$ & $0.86(0.48,1.54)$ & 0.62 & - & \\
\hline \multicolumn{7}{|l|}{ SES Index } \\
\hline Poor & $21(11.6)$ & $160(88.4)$ & 1.00 & & - & \\
\hline Middle & $23(12.7)$ & $158(87.3)$ & $1.12(0.59,2.09)$ & 0.75 & - & \\
\hline Rich & $8(8.8)$ & $83(91.2)$ & $0.73(0.31,1.73)$ & 0.48 & - & \\
\hline \multicolumn{7}{|c|}{ Maternal literacy } \\
\hline Literate & $6(5.2)$ & $109(94.8)$ & 1.00 & & 1.00 & \\
\hline Illiterate & 46 (13.6) & $292(86.4)$ & $2.86(1.19,6.89)$ & 0.02 & $2.30(0.94,5.63)$ & 0.07 \\
\hline \multicolumn{7}{|c|}{ Paternal literacy } \\
\hline Literate & $16(12.0)$ & $117(88.0)$ & 1.00 & & - & \\
\hline Illiterate & $36(11.2)$ & $284(88.8)$ & $0.93(0.49,1.74)$ & 0.81 & - & \\
\hline \multicolumn{7}{|c|}{ Maternal occupation } \\
\hline Employed & $5(8.6)$ & $53(91.4)$ & 1.00 & & - & \\
\hline Unemployed & $47(11.9)$ & $348(88.1)$ & $1.43(0.55,3.76)$ & 0.47 & - & \\
\hline \multicolumn{7}{|c|}{ Paternal occupation } \\
\hline Employed & $37(9.1)$ & $368(90.9)$ & 1.00 & & 1.00 & \\
\hline Unemployed & $15(31.2)$ & $33(68.8)$ & $4.96(2.49,9.86)$ & $<0.001$ & $4.28(2.13,8.63)$ & $<0.001$ \\
\hline Total & 52 & 401 & & & & \\
\hline
\end{tabular}

intestinal helminth infections and children's growth in a study carried out in São Paulo, Brazil [17].

The prevalence of S. mansoni infection was $53.2 \%$ which is considered a high prevalence according to WHO classification of prevalence of S. mansoni [34]. Stunting was not statistically associated with S. mansoni infection. This was not the case in a previous crosssectional study in the northeastern Brazilian town of Nazaré, Bahia [35]. In this study, children infected with $S$. mansoni were significantly more malnourished than children with a negative stool sample for several anthropometric variables. The reason for this contradicting finding could be due to difference in transmission of geo-helminthes. The study population in Brazil was highly infected with soil transmitted helminthes (STHs). The prevalence of Ascaris lumbricoides and Trichuris trichiura infections among those children were 71.8 and
$67.9 \%$, respectively. However, in our case none of the STHs were detected in stool examination. One major reason for the absence of STHs in our study area could be the regular administration of anti-helminthic (mass chemotherapy) to children at the beginning of every school year according the source of the Fincha'a health center authorities.

It has been reported that intestinal helminthiasis may play a contributory role in the occurrence of childhood malnutrition [29,36,37]. One reason why our reports contradicts with the finding of the Brazil study might be that in endemic areas where more than one species of parasite prevails and that the interaction of these parasites with each other may modulate or change the parasite nutritional status relationships. Hence, we presume that a synergistic effect of STH and S. mansoni infection could be accountable for the nutritional deficit. Furthermore, the 
Table 3 Bivariate and multivariate logistic regression analysis of factors associated with wasting amongst school age children residing in Fincha'a Sugar Estate, Horo Guduru Wollega, Ethiopia, Feb-Mar, 2011

\begin{tabular}{|c|c|c|c|c|c|c|}
\hline Variables & $\begin{array}{c}\text { Wasted } \\
\text { n (\%) }\end{array}$ & $\begin{array}{c}\text { Normal } \\
\text { n (\%) }\end{array}$ & $\begin{array}{c}\text { COR } \\
(95 \% \mathrm{Cl}) \\
\end{array}$ & P-value & $\begin{array}{c}\text { AOR } \\
(95 \% \mathrm{Cl}) \\
\end{array}$ & P-value \\
\hline \multicolumn{7}{|l|}{ Gender } \\
\hline Female & $19(8.0)$ & $218(91.0)$ & 1.00 & & 1.00 & \\
\hline Male & $41(19.0)$ & $175(81.0)$ & $2.69(1.51,4.79)$ & 0.001 & $2.18(1.19,3.96)$ & 0.01 \\
\hline \multicolumn{7}{|l|}{ Age group } \\
\hline $5-9$ & $11(9.5)$ & $105(90.5)$ & 1.00 & & - & \\
\hline $10-14$ & $38(13.4)$ & $246(86.6)$ & $1.29(0.65,2.59)$ & 0.46 & - & \\
\hline $15-18$ & $11(20.7)$ & $42(79.3)$ & $2.27(0.93,5.55)$ & 0.07 & - & \\
\hline \multicolumn{7}{|l|}{ S. mansoni } \\
\hline Uninfected & $38(17.9)$ & $174(82.1)$ & 1.00 & & 1.00 & \\
\hline Infected & $22(9.1)$ & $219(90.9)$ & $0.46(0.26,0.81)$ & 0.01 & $0.45(0.25,0.81)$ & 0.00 \\
\hline \multicolumn{7}{|l|}{ SES Index } \\
\hline Poor & $25(13.8)$ & $156(86.2)$ & 1.00 & & - & \\
\hline Middle & $20(11.0)$ & $161(89.0)$ & $0.78(0.41,1.45)$ & 0.43 & - & \\
\hline Rich & $15(16.5)$ & $76(83.5)$ & $1.23(0.61,2.47)$ & 0.56 & - & \\
\hline \multicolumn{7}{|c|}{ Maternal Literacy } \\
\hline Literate & $5(4.3)$ & $110(95.7)$ & 1.00 & & 1.00 & \\
\hline Illiterate & $55(16.3)$ & $283(83.7)$ & $4.28(1.67,10.96)$ & 0.002 & $3.56(1.36,9.30)$ & 0.01 \\
\hline \multicolumn{7}{|c|}{ Paternal literacy } \\
\hline Literate & $15(11.3)$ & $118(88.7)$ & 1.00 & & - & \\
\hline Illiterate & $45(14.2)$ & $272(85.8)$ & $1.29(0.69,2.40)$ & 0.43 & - & \\
\hline \multicolumn{7}{|c|}{ Maternal occupation } \\
\hline Employed & $5(8.6)$ & $53(91.4)$ & 1.00 & & - & \\
\hline Unemployed & $55(13.9)$ & $340(86.1)$ & $1.72(0.66,4.48)$ & 0.27 & - & \\
\hline \multicolumn{7}{|c|}{ Paternal occupation } \\
\hline Employed & $43(10.6)$ & $361(89.4)$ & 1.00 & & 1.00 & \\
\hline Unemployed & $17(34.7)$ & $32(65.3)$ & $4.46(2.29,8.69)$ & 0.00 & $3.83(1.89,7.79)$ & 0.00 \\
\hline Total & 60 & 393 & & & & \\
\hline
\end{tabular}

nutritional status of our participants might have been boosted by subsequent treatments.

In contrary to stunting S. mansoni was associated with wasting. However, the relation was surprising that infected children were less likely to be wasted than their uninfected counterparts. Wasting indicates recent nutritional condition and is generally associated with recent illness and failure to gain weight or a loss of weight [38]. S. mansoni infection, on the other hand, is a chronic disease and it's relation with undernutrition is better explained by stunting. Therefore, we assumed long-term linear growth retardation might have relative protection of weight and height based indices (BAZ). Similar scenario has been reported in Philippines [39].

Our results on socio-economic status showed that Father's occupation was the best predictor of both stunting and wasting among school age children. Similar study conducted in India indicated that the poor nutritional status was associated with socioeconomic variables such as sex of the child and father's occupation [40]. In contrast to this, the study conducted in Peru and Peruvian Andes showed that father's engagement on any type of occupation did not have differential impact on child undernutrition [41].

Moreover, the results of the study indicated that there seemed a conflicting relationship between SES of no association and paternal employment as a predictor of stunting/wasting. Although, most of the time wealth index is taken as proxy to employment, this conflicting relationship could be justified as 1) paternal employment might not necessarily be reliable indicator for wealth index in the study area and 2) most of the time, people do not disclose genuine enough information on their SES. 
Our finding of maternal literacy as an associated factor with wasting is in line with the findings of several other studies conducted in India [40], Pakistan [42] Bolivia [43] Kenya [44] and Jamaica [45] which indicated that uneducated mothers were likely to have malnourished children than those educated. In contrast to the above findings, study conducted by Mazumdar in Egypt did not find any significant relationship between long-run child undernutrition indicator (stunting) and maternal education [46]. However, as undernutrition is the product of the interaction of many factors and confounded by those factors [38], it is difficult to reach on conclusive comparison on similarity and differences among different studies including the present study.

\section{Limitation of the study}

We acknowledge inaccuracy of the age of the included children (for some of our study subjects) due to lack of birth certificates and recall bias that can be considered as one of the limitation of this study. Moreover, we use only BMI which depends upon weight and the square of height, it ignores basic scaling laws whereby mass increases to the $3^{\text {rd }}$ power of linear dimensions. Lastly we admit the effect of the study design as well.

\section{Conclusion}

The high prevalence of $S$. mansoni infection and wasting, moderate level of stunting, and observed significant association mean that school children in these schistosomiasis endemic areas were affected by both infection and undernutrition. Therefore, regular screening and provision of mass treatment (preventive chemotherapy) against $S$. mansoni infections with other control measures are recommended. Moreover, possibilities of synchronized nutritional rehabilitation and creation of employment opportunities to the family of the child should be looked for.

\footnotetext{
Abbreviations

HAZ: Height-for-Age Z-score; BAZ: Body mass index for-Age Z-score; BMI: Body mass index; SD: Standard deviations; AOR: Adjusted odds ratio; epg: Eggs per gram.
}

\section{Competing interests}

The authors declared that they have no competing interests.

\section{Authors' contributions}

SM participated in proposal write up, data collection, analysis, interpretation, drafting of the manuscript. All other authors (ZM, SM, AZ, and SS) participated in data analysis and interpretation, and critical review of the manuscript. In addition ZM was part of the initiation of the research idea participated in proposal write up and critically reviewed the manuscript and overall write-up. All authors read and approved the final manuscript.

\section{Acknowledgements}

We thank Jimma University Postgraduate School and VLIR-JU/IUC project for supporting the study financially. We are also very grateful to Fincha'a Sugar Estate factory managements and community representatives of the villages. Our gratitude also extends to the study participants who voluntarily participated in the study.

\section{Author details}

${ }^{1}$ Department of Medical Laboratory Sciences and Pathology, College of Public Health and Medical Sciences, Jimma University, P.O. Box 378, Jimma, Ethiopia. ${ }^{2}$ Department of Pharmacy, College of Public Health and Medical Sciences, Jimma University, P.O. Box 378, Jimma, Ethiopia.

Received: 6 January 2014 Accepted: 14 October 2014 Published: 27 October 2014

\section{References}

1. Best C, Neufingerl N, van Geel L, van den Briel T, Osendarp S: The nutritional status of school-aged children: Why should we care? Food Nutr Bull 2010, 31(3):400-417.

2. Drake L: School-age children: Their Nutrition and Health. Partnership for Child Development. Department of Infectious Disease Epidemiology. London, UK: Imperial College; 2002. SCN News, 2002; No. 25.

3. Jukes $M$ : The long-term impact of preschool health and nutrition on education. Food Nutr Bull 2005, 26(Suppl 2):S193-S201.

4. Stoltzfus RJ, Albonico M, Tielsch JM, Chwaya HM, Savioli L: Linear growth retardation in Zanzibari school children. J Nutr 1997, 127:1099-1105.

5. Parraga IM, Assis AM, Prado MS, Barreto ML, Reis MG, King CH, Blanton RE: Gender differences in growth of school-aged children with schistosomiasis and geohelminth infection. Am J Trop Med Hyg 1996, 5:150-156.

6. Nguyen NL, Gelaye B, Aboset N, Kumie A, Williams MA, Berhane Y: Intestinal parasitic infection and nutritional status among school children in Angolela, Ethiopia. J Prev Med Hyg 2012, 53(3):157-164.

7. De Stefano GF, De Angelis F: Anthropometric growth pattern in Ethiopian infants and children: an evaluation based on different international growth references. Coll Antropol 2009, 33(3):729-734.

8. De Onis M, Monteiro C, Akre J, Glugston G: The worldwide magnitude of protein- energy malnutrition: an overview from the WHO Global Database on Child Growth. Bull World Health Organ 1993, 71:703-712.

9. Alasfoor D, Elsayed MK, Al-Qasmi AM, Malankar P, Sheth M, Prakash N: Protein-energy malnutrition among preschool children in Oman: results of a national survey. East Mediterr Heal J 2007, 13(5):1022-1030.

10. Musgrove P: Investing in health: The 1993 World Development Report of the World Bank. Bull Pan Am Health Organ 1993, 27:284-286.

11. Stephenson LS, Latham MC, Ottesen EA: Malnutrition and parasitic helminth infections. Parasitology 2000, 121(Suppl):S23-S38.

12. Katona $\mathrm{P}$, Katona-Apte $\mathrm{J}$ : The interaction between nutrition and infection. Clin Infect Dis 2008, 46(10):1582-1588.

13. Apier K, Williams GM, Luceres-Catubig R, Ahmed F, Olveda RM, McManus DP, Chy D, Chau TN, Gray DJ, Ross AG: Childhood malnutrition and parasitic helminth interactions. Clin Infect Dis 2014, 59(2):234-243.

14. Hughes RG, Sharp DS, Hughes MC, Akau'ola S, Heinsbroek P, Velayudhan R, Schulz D, Palmer K, Cavalli-Sforza T, Galea G: Environmental influences on helminthiasis and nutritional status among Pacific schoolchildren. Int J Environ Health Res Taylor \& Francis 2004, 14(3):163-177.

15. Beltrame A, Scolari C, Torti C, Urbani C: Soil transmitted helminth (STH) infections in an indigenous community in Ortigueira, Paraná, Brazil and relationship with its nutritional status. Parassitologia 2002, 44:137-139.

16. Quihui-Cota L, Valencia ME, Crompton DW, Phillips S, Hagan P, DiazCamacho SP, TrianaTejas A: Prevalence and intensity of intestinal parasitic infections in relation to nutritional status in Mexican schoolchildren. Trans R Soc Trop Med Hyg 2004, 98:653-659.

17. Muniz PT, Ferreira MU, Ferreira CS, Conde WL, Monteiro CA: Intestinal parasitic infections in young children in Sao Paulo, Brazil: prevalences, temporal trends and associations with physical growth. Ann Trop Med Parasitol 2002, 96:503-512.

18. Gurarie D, Wang $X$, Bustinduy AL, King CH: Modeling the effect of chronic schistosomiasis on childhood development and the potential for catch-up growth with different drug treatment strategies promoted for control of endemic schistosomiasis. Am J Trop Med Hyg 2011, 84(5):773-781.

19. Uneke C, Egede M: Impact of Urinary Schistosomiasis on Nutritional Status of School Children in South-Eastern Nigeria. Internet J Health 2008, 9:1-5.

20. Assis AM, Barreto ML, Prado MS, Reis MG, Parraga IM, Blanton RE: Schistosoma mansoni infection and nutritional status in schoolchildren: a randomized, double-blind trial in north-eastern Brazil. Am J Clin Nutr 1998, 68:1247-1253. 
21. De Gier B, Campos Ponce $M$, van de Bor M, Doak CM, Polman K: Helminth infections and micronutrients in school-age children: a systematic review and meta-analysis. Am J Clin Nutr 2014, 99(6):1499-1509.

22. Central Statistical Authority (Ethiopia): Report on (1998 E.C) Health and Nutrition Survey. Addis Ababa: CSA; 1999.

23. Central Statistical Authority (Ethiopia) and OCR Macro: Ethiopia Demographic and Health Survey. Addis Ababa, Ethiopia and Calverton, Maryland, U.S.A: Central Statistical Authority and OCR Macro; 2005.

24. Filmer D, Pritchett LH: Estimating wealth effects without expenditure data-or tears: an application to educational enrollments in states of India. Demography 2001, 38:115-132.

25. Tarafder MR, Carabin H, Joseph L, Balolong E, Olveda R, McGarvey ST: Estimating the sensitivity and specificity of Kato-Katz stool examination technique for detection of hookworms, Ascaris lumbricoides and Trichuris trichiura infections in humans in the absence of a 'gold standard'. Int J Parasitol 2010, 40:399-404

26. World Health Organization: Guidelines for the evaluation of soil-transmitted helminthiasis and schistosomiasis at community level. Geneva: Document of World Health Organization; 1999. WHO/CTD/SIP/98.1.

27. Bailey KV, Ferro-Luzzi A: Use of body mass index of adults in assessing individual and community nutritional status. Bull World Health Organ 1995, 73:673-680.

28. United Nations-Administrative Committee on Coordination/Sub-Committee on Nutrition: Third Report on the World Nutrition Situation. Geneva: United Nations (ACC/SCN); 1997

29. Jardim-Botelho A, Brooker S, Geiger SM, Fleming F, Souza Lopes AC, Diemert DJ, Correa-Oliveira R, Bethony JM: Age patterns in undernutrition and helminth infection in a rural area of Brazil: associations with ascariasis and hookworm. Trop Med Int Health 2008, 13(4):458-467.

30. De Onis M, Blossner M: WHO Global Database on child growth and malnutrition. Geneva: World Health Organization; 1997. Programme of Nutrition/97/4

31. Casapía M, Joseph SA, Núñez C, Rahme E, Gyorkos TW: Parasite risk factors for stunting in grade 5 students in a community of extreme poverty in Peru. Int J Parasitol 2006, 36:741-747.

32. Tshikuka JG, Gray-Donald K, Scott M, Olela KN: Relationship of childhood protein-energy malnutrition and parasite infections in an urban African setting. Trop Med Int Health 1997, 2:374-382.

33. Khuwaja S, Selwyn BJ, Shah SM: Prevalence and correlates of stunting among primary school children in rural areas of Southern Pakistan. J Trop Pediatr 2005, 51:72-77.

34. World Health Organization: Prevention and control of schistosomiasis and the soil-transmitted helminthiasis, WHO Technical Report Series No. 912. Geneva: World Health Organization; 2002.

35. Assis AM, Prado MS, Barreto ML, Reis MG, Conceicao Pinheiro SM, Parraga IM, Blanton RE: Childhood stunting in Northeast Brazil: the role of $S$. mansoni infection and inadequate dietary intake. Eur J Clin Nutr 2004, 58:1022-1029

36. Dancesco P, Akakpo C, lamandi I, Abeu J, Tshipeta M, Kacou E: Intestinal parasitoses in a village of Cote d'Ivoire: Relationship between intestinal parasitoses, physical and physiological development and child nutrition. Sante 2005, 15:11-16.

37. Oninla SO, Onayade AA, Owa JA: Impact of intestinal helminthiases on the nutritional status of primary-school children in Osun state, south-western Nigeria. Ann Trop Med Parasitol 2010, 104:583-594.

38. De Onis M, Monika Blössner M, World Health Organization: Global Database on Child Growth and Malnutrition. Geneva: WHO; 1997. WHO/NUT/97.4

39. Friedman JF, Kanzaria HK, Acosta LP, Langdon GC, Manalo DL, Wu H, Olveda RM, McGarvey ST, Kurtis JD: Relationship between Schistosoma japonicum and nutritional status among children and young adults in Leyte, the Philippines. Am J Trop Med Hyg 2005, 72:527-533.

40. Saito K, Korzenik JR, Jekel JF, Bhattacharji S: A case-control study of maternal knowledge of malnutrition and health-care-seeking attitudes in rural South India. Yale J Biol Med 1997, 70(2):149-160.

41. Helga BU, Torill B, Maurice BM: Socioeconomic Status and Chronic Child Malnutrition: Wealth and Maternal Education Matter More in the Peruvian Andes than Nationally. Nutr Res 2011, 31:741-747.

42. Aslam M, Kingdon GG: Parental Education and Child Health Understanding the Pathways of Impact in Pakistan. University of London, UK 2012, 40(10):2014-2032
43. Frost MB, Forste R, Haas DW: Maternal education and child nutritional status in Bolivia: finding the links. Soc Sci Med 2005, 60(2):395-407.

44. Abuya BA, Onsomu EO, Kimani JK, Moore D: Influence of Maternal Education on Child Immunization and Stunting in Kenya. Matern Child Health J 2011, 15:1389-1399.

45. Handa S: Maternal Education and Child Height. Econ Devel Cult Change 1999, 47(2):421-439.

46. Mazumdar S: Assessing Vulnerability to Chronic Undernutrition among Under-Five Children in Egypt: Contextual Determinants of an Individual Consequence. Int J Popul Res 2012, http://dx.doi.org/10.1155/2012/939541.

doi:10.1186/1756-0500-7-763

Cite this article as: Mekonnen et al:: Schistosoma mansoni infection and undernutrition among school age children in Fincha'a sugar estate, rural part of West Ethiopia. BMC Research Notes 2014 7:763.

\section{Submit your next manuscript to BioMed Central and take full advantage of:}

- Convenient online submission

- Thorough peer review

- No space constraints or color figure charges

- Immediate publication on acceptance

- Inclusion in PubMed, CAS, Scopus and Google Scholar

- Research which is freely available for redistribution 